\title{
H1N1 vaccine and narcolepsy link discovered
}

$\mathrm{R}$ esearchers have found a clue to the cases of narcolepsy seen after H1N1 infection and vaccination that also sheds light on the safety of vaccines and adjuvants. A study published July 1 in Science Translational Medicine shows that a nuclear protein found in both $\mathrm{H} 1 \mathrm{~N} 1$ influenza virus and some H1N1 vaccines blocks a receptor for hypocretin, a neuropeptide associated with wakefulness. But it only affects people with a specific genetic make-up (human leukocyte antigen [HLA] haplotype) that is rare in Canada, but more common in the northern European countries.

The research team compared a vaccine that has been associated with narcolepsy (Pandemrix, GlaxoSmithKline) with one that has not (Focetria, Novartis), to see if any differences between them matched the proteins involved in narcolepsy. One difference was a peptide from a nuclear protein in the H1N1 virus itself that mimics the hypocretin receptor.

"That was a surprise to us," said one of the principal authors, Dr. Sohail Ahmed, who, with co-author Dr. Lawrence Steinman, a neurologist at Stanford University, Palo Alto, California, has been searching for this piece of the puzzle for several years. (Ahmed was with Novartis throughout the study, but is now with GlaxoSmithKline, which aquired most of Novartis' vaccines business in January 2015.)

Focetria contains $72.7 \%$ less of the influenza nuclear protein than Pandemrix, which is thought to have led to the difference in narcolepsy effects.

An article published in December 2013 by a different research team had proposed a similar link, but was retracted in July 2014 when the authors were unable to replicate a key part of the mechanism.

The recent study's findings mean that H1N1 infection, as well as vaccination, can cause narcolepsy. Ahmed explained that the infection causes a greater immune response, and is a stronger trigger for narcolepsy, than the vaccine.

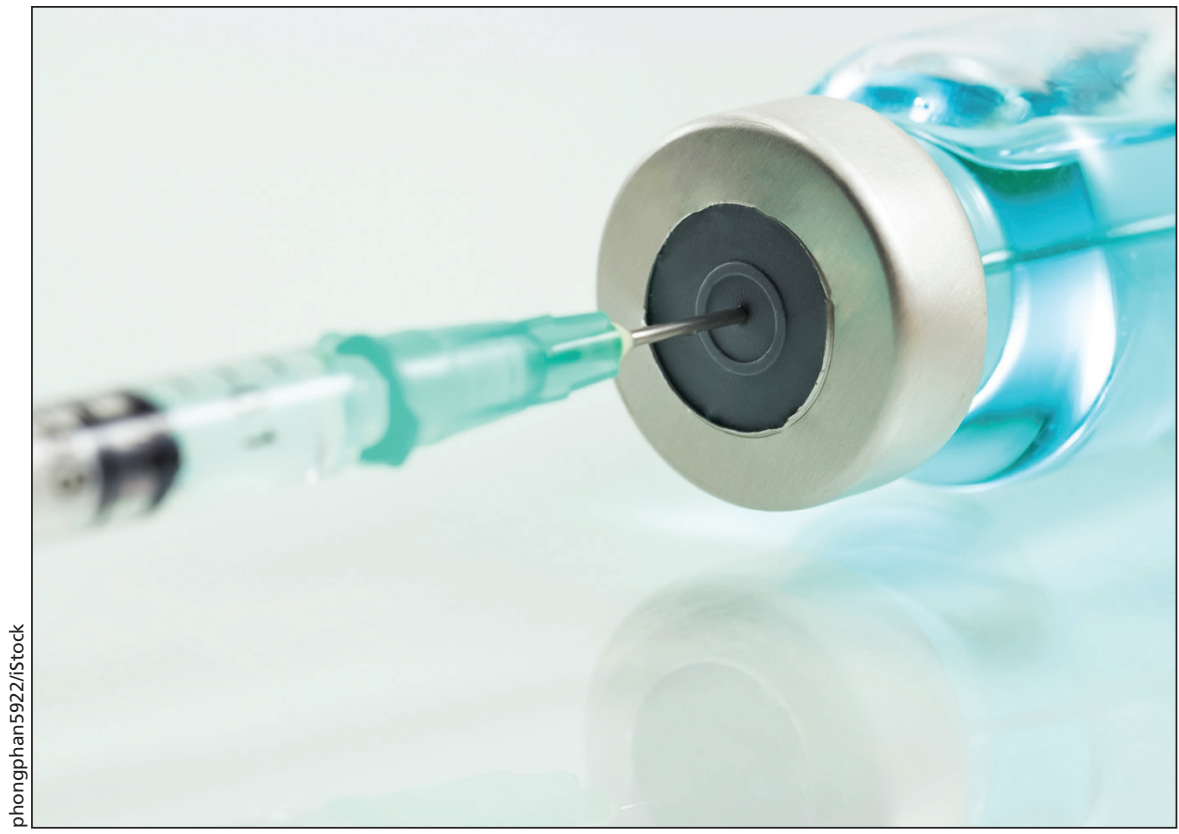

A protein found in H1N1 and some vaccines that prevent it, is associated with narcolepsy in a small group of people with a specific genetic make-up.

"This makes getting vaccinated even more important, because the wild disease is worse," said Dr. Noni MacDonald, professor of paediatrics at Dalhousie University, Halifax, and coauthor of a previous review on the subject with Ahmed and Steinman.

Rates of narcolepsy after the H1N1 pandemic were very low in Canada. A study in Quebec found that seven cases were associated with vaccination, for a rate of about one case per million vaccine doses, 1.5 to 2 times higher than normal. The vaccine used in Canada was Arepanrix, manufactured by GlaxoSmithKline, which "likely has the same amount of nuclear protein" as Pandemrix, said MacDonald. Arepanrix was not included in the recent study.

Several studies, including this new one, have found a link with a genetic HLA haplotype. "Very, very few percent of the [Canadian] population would carry that gene" according to genetic studies, said Ahmed, whereas it is common in northern European countries. "That would explain some of the difference in the distribution that we would see."

The study clarifies the role of the AS-03 adjuvant used in Pandemrix and Arepanrix. "It doesn't look like the adjuvant is likely involved at all," said MacDonald. Focetria vaccine, which did not cause narcolepsy, had an adjuvant, and infection with the virus alone can cause narcolepsy. MacDonald points out that narcolepsy - called "encephalitis lethargica" - was a common aftereffect of the Spanish influenza pandemic of 1918.

MacDonald said the finding may quickly lead to safer vaccines. "I think the vaccine safety question can be easily solved, because there are some manufacturing processes that can take nuclear protein out." An international research meeting is being planned for Geneva, Switzerland, in October 2015 to discuss the links between narcolepsy and influenza as well as influenza vaccines. Carolyn Brown, Ottawa

CMAJ 2015. DOI:10.1503/cmaj.109-5118 